\title{
Biomaterial-Based Activation and Expansion of Tumor-Specific T Cells
}

\author{
Marjolein Schluck ${ }^{1,2}$, Roel Hammink ${ }^{1,2}$, Carl G. Figdor ${ }^{1,2,3}$, Martijn Verdoes $^{1,3 *}$ and \\ Jorieke Weiden ${ }^{1,2,3 *+}$
}

${ }^{1}$ Department of Tumor Immunology, Radboud Institute for Molecular Life Sciences, Radboud University Medical Center, Nijmegen, Netherlands, ${ }^{2}$ Division of Immunotherapy, Oncode Institute, Radboud University Medical Center, Nijmegen, Netherlands, ${ }^{3}$ Institute for Chemical Immunology, Nijmegen, Netherlands

\section{OPEN ACCESS}

Edited by:

Roberto S. Accolla,

University of Insubria, Italy

Reviewed by:

Paolo Dellabona,

San Raffaele Scientific Institute

(IRCCS), Italy

Lenka V. Hurton,

University of Texas MD Anderson

Cancer Center, United States

Markus W. Löffler,

University of Tübingen, Germany

${ }^{*}$ Correspondence:

Martijn Verdoes

martijn.verdoes@radboudumc.nl

Jorieke Weiden

jorieke.weiden@radboudumc.n

${ }^{\dagger}$ These authors have contributed equally to this work

Specialty section:

This article was submitted to Cancer Immunity and Immunotherapy, a section of the journal

Frontiers in Immunology

Received: 14 February 2019 Accepted: 11 April 2019

Published: 03 May 2019

Citation:

Schluck M, Hammink R, Figdor CG, Verdoes M and Weiden J (2019)

Biomaterial-Based Activation and Expansion of Tumor-Specific T Cells.

Front. Immunol. 10:931.

doi: 10.3389/fimmu.2019.00931
Traditional tumor vaccination approaches mostly focus on activating dendritic cells (DCs) by providing them with a source of tumor antigens and/or adjuvants, which in turn activate tumor-reactive $T$ cells. Novel biomaterial-based cancer immunotherapeutic strategies focus on directly activating and stimulating $T$ cells through molecular cues presented on synthetic constructs with the aim of improving $T$ cell survival, more precisely steer $T$ cell activation and direct $T$ cell differentiation. Synthetic artificial antigen presenting cells (aAPCs) decorated with T cell-activating ligands are being developed to induce robust tumor-specific $T$ cell responses, essentially bypassing DCs. In this perspective, we approach these promising new technologies from an immunological angle, first by identifying the $\mathrm{CD}^{+}$and $\mathrm{CD}^{+}{ }^{+} \mathrm{T}$ cell subtypes that are imperative for robust anti-cancer immunity and subsequently discussing the molecular cues needed to induce these cells types. We will elaborate on how biomaterials can be applied to stimulate $T$ cells in vitro and in vivo to improve their survival, activation and function. Scaffold-based methods can also be used as delivery vehicles for adoptive transfer of T cells, including tumor-infiltrating lymphocytes (TILs) and chimeric antigen receptor expressing (CAR) T cells, while simultaneously stimulating these cells. Finally, we provide suggestions on how these insights could advance the field of biomaterial-based activation and expansion of tumor-specific T cells in the future.

Keywords: cancer immunotherapy, biomaterials, $\mathrm{T}$ cells, artificial antigen-presenting cells, scaffold, anti-tumor immune response, synthetic immune niche, molecular cues

\section{INTRODUCTION}

Immunotherapy provides a revolutionary treatment modality for cancer. A variety of strategies have been developed to improve the clinical outcome of patients by generating long-term anti-tumor immune responses. The development of therapeutic monoclonal antibodies that block co-inhibitory receptors on T cells, such as cytotoxic T-lymphocyte-associated antigen 4 (CTLA-4) and programmed death 1 (PD-1), has shown exceptional clinical benefit in cancer patients and is seen as a crucial breakthrough in the cancer immunotherapy field (1).

Apart from relieving suppression in pre-existing $\mathrm{T}$ cells, other immunotherapeutic strategies focus on increasing the number of tumor-reactive $\mathrm{T}$ lymphocytes that recognize either tumor-specific antigens, tumor-associated antigens, cancer-testis antigens or neo-antigens. Dendritic cell (DC) vaccination targets antigen-presenting DCs, which are capable of priming $\mathrm{T}$ cells by capturing, processing and presenting antigens to naïve $\mathrm{T}$ cells together with 
co-stimulatory cues (2). To generate DC vaccines, patientderived DCs are cultured ex vivo, maturated and loaded with antigens, after which they are infused back into the patient where they activate tumor-reactive $T$ cells (3). Increased overall survival, functional tumor-specific immune responses and low toxicities have been observed with this strategy $(4,5)$. Other cell-based therapies attempt to increase the number of circulating tumor-specific $\mathrm{T}$ cells by reinfusing autologous ex vivo-expanded $\mathrm{T}$ cells derived from tumors (tumor-infiltrating lymphocytes, TIL) or genetically engineering them to confer tumor reactivity using high affinity T-cell receptors (TCR) or chimeric antigen receptors (CAR) (6). Promising preclinical data have been obtained with these adoptive T-cell therapies $(1,7,8)$. The prominent immunotherapeutic strategies described above all focus on generating robust tumor-directed $\mathrm{T}$ cell responses, which is crucial to inducing effective and longlasting anti-tumor immunity, as there is a strong correlation between tumor-infiltrating $\mathrm{CD} 8^{+} \mathrm{T}$ cells and patient survival in virtually all cancer types (9). In addition, antigen-specific $\mathrm{CD}^{+} \mathrm{T}$ helper cells are believed to be critically involved in the induction of optimal anti-tumor responses $(10,11)$. It is therefore evident that $\mathrm{T}$ cells play a central role in cancer immunotherapy.

Although current cancer immune therapies have shown promising preclinical and clinical results, challenges remain that may limit therapeutic benefit. To improve on this and to design new therapeutic strategies, interest in the field of biomaterial engineering has grown. Biomaterials have proven valuable in reducing systemic toxicities, enhancing accumulation in tumors, improving pharmacokinetics and ensuring sustained release by controlled (targeted) drug delivery $(12,13)$. Biomaterialbased immunotherapeutic strategies led to the development of nanoparticles for the targeted delivery of cargo to immune cells in vivo, such as cytokines, DC-activating agents or small inhibitors (13-15). Careful design can be applied to tune the delivery of DC-targeted vaccines using materials responsive to temperature $(16)$ or $\mathrm{pH}(17,18)$. Other biomaterial-based approaches focus on improving ex vivo immune cell expansion or on supporting immune cells after adoptive transfer $(13,14)$. Furthermore, there has been a rise in the development of synthetic, acellular artificial antigen presenting cells (aAPCs) that can target and activate $\mathrm{T}$ cells directly $(19,20)$, thereby bypassing the need for DC activation. By presenting molecular cues on synthetic constructs based on biomaterials, specific signals are transmitted to $\mathrm{T}$ cells in a well-defined context and controlled manner to support $\mathrm{T}$ cell viability, activation and differentiation.

In this perspective, we will detail what $\mathrm{T}$ cell subtypes are imperative for robust anti-cancer immunity and which molecular cues are needed to induce these $\mathrm{T}$ cells. Next, we will elaborate on how these molecular cues can be presented by biomaterials for direct activation and expansion of $\mathrm{T}$ cells. The use of biomaterials to aid the adoptive transfer of $\mathrm{T}$ cells will also be discussed. Finally, we will illustrate in which direction the field of biomaterial engineering for cancer immunotherapy should go for the next generation of biomaterialbased cancer immunotherapies.

\section{T CELL SUBSETS IN CANCER IMMUNOTHERAPY}

To generate durable anti-tumor immune responses that have a beneficial impact on the clinical outcome of cancer patients, potent $\mathrm{CD} 8^{+}$and $\mathrm{CD} 4^{+} \mathrm{T}$ cell responses are crucial (9-11). Here, we will discuss the roles of different $\mathrm{T}$ cell subtypes in cancer-specific immune responses and we will highlight the cellular and molecular characteristics of these T cells (Figure 1).

Upon interaction with their cognate antigen in the context of major histocompatibility complex class I (MHC I) and co-stimulatory cues, $\mathrm{CD}^{+} \mathrm{T}$ cells will undergo extensive proliferative expansion to create a large population of short-lived effector cytotoxic T lymphocytes (CTLs) that have tumor-killing capacities. The CTL population comprises functionally distinct subsets (21). For instance, expression of CX3CR1 on CTLs is associated with their ability to generate memory subsets and serves as a predictor for CX3CR1 expression on the generated memory cells, which is associated with robust cytotoxic effector functions $(22,23)$. CXCR5-expressing CTLs are involved in chronic viral infections and show reduced susceptibility to exhaustion (24). Additional heterogeneity may exist regarding cytokine production and the (co-)expression of perforin and various granzymes (25). In addition to these short-lived CTLs, the formation of $\mathrm{CD}^{+}$memory $\mathrm{T}$ cells is required to support long-term anti-tumor immunity. Following a progressive differentiation model, primed naive $\mathrm{CD}^{+} \mathrm{T}$ cells (Tn) will progress into different memory $\mathrm{T}$ cell populations [T stem cell memory $(\mathrm{Tscm}), \mathrm{T}$ central memory $(\mathrm{Tcm}), \mathrm{T}$ effector memory (Tem)] (21, 22, 25-27). The Tscm subset displays increased anti-tumor activity, enhanced proliferation, increased survival capacities and multipotency $(27,28)$. The $\mathrm{Tcm}$ generally have higher proliferative abilities while Tem are more cytotoxic (22). In contrast to circulating memory $\mathrm{T}$ cells, there is also a population of non-circulating memory $\mathrm{T}$ cells, tissue resident memory $\mathrm{T}$ cells (Trm). These Trm cells were shown to be superior in providing rapid long-term protection against recurrent infections (29). Inducing a broad repertoire of potent CTLs together with CD8 ${ }^{+}$memory T cells will be highly beneficial for robust anti-tumor immunity (Figure 1A).

$\mathrm{CD}^{+} \mathrm{T}$ cell help is imperative for potent $\mathrm{CD}^{+} \mathrm{T}$ cell activation by supplying cytokines and co-stimulation, by enhancing persistence and migration, and by reactivating memory CD8 ${ }^{+} \mathrm{T}$ cells (30-32). Recently, it has been reported that $\mathrm{CD}^{+} \mathrm{T}$ cells are also dependent on $\mathrm{CD} 8^{+} \mathrm{T}$ cells, underlining the mutual dependence of $\mathrm{CD}^{+}$and $\mathrm{CD}^{+} \mathrm{T}$ cell responses (10). Furthermore, a RNA vaccination study clearly showed the importance of $\mathrm{CD}^{+} \mathrm{T}$ cell neo-epitopes in controlling murine tumors (11). The $\mathrm{CD} 4^{+} \mathrm{T}$ cell population can be subdivided into specific subsets, each having their own signature cytokine repertoire $(33,34)$. The $\mathrm{T}$ helper 1 (Th1) subset is strongly associated with better prognosis, improved survival, low incidence of tumor recurrence and prolonged disease-free survival in cancer immunology (35). This is in part due to their supportive role in cellular immunity, the cytokines they produce [including interferon- $\gamma(\operatorname{IFN}-\gamma)$ ] (35), and their role in inducing immunological memory (36). In addition, notable 


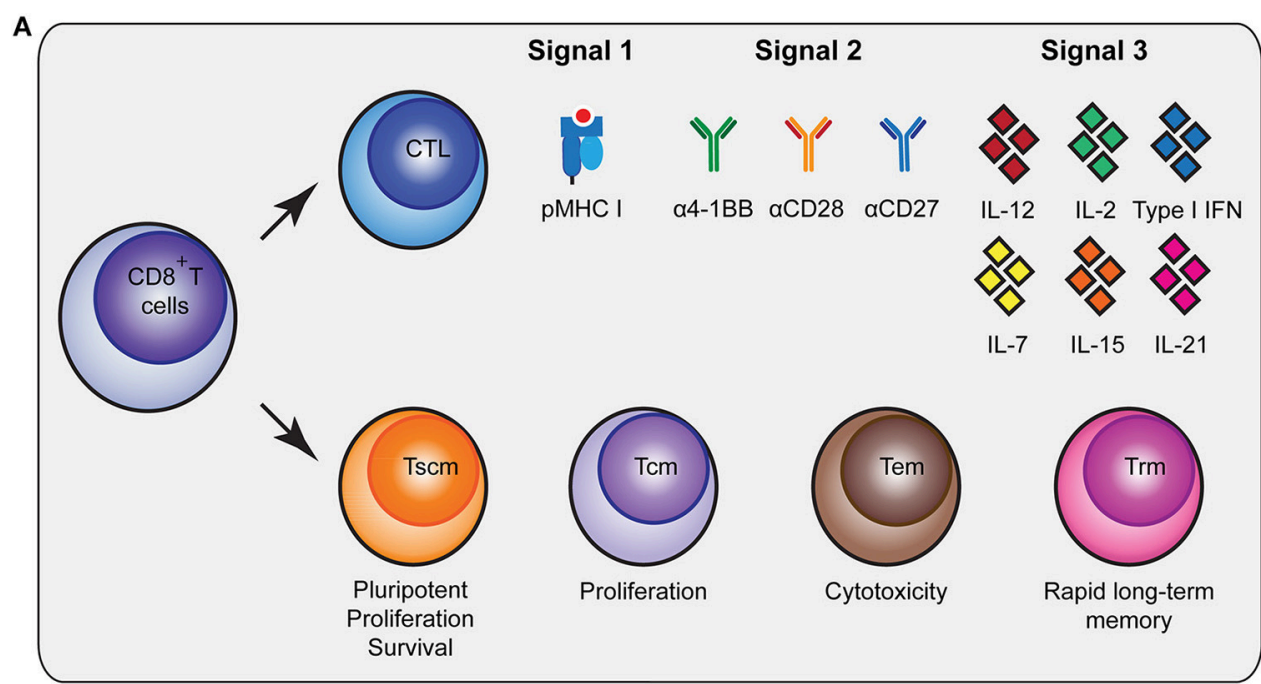

B

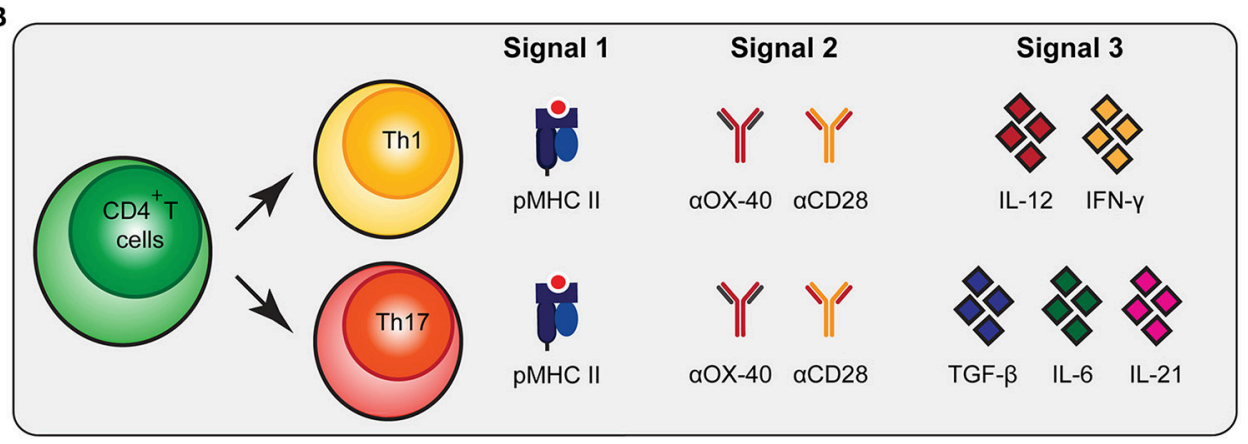

FIGURE 1 | Molecular cues involved in $\mathrm{CD}^{+}$and $\mathrm{CD} 4^{+} \mathrm{T}$ cell activation and differentiation. (A) CD8 ${ }^{+} \mathrm{T}$ cells can be subdivided in cytoxic T lymphocytes (CTLs) and memory subsets [memory stem cells (Tscm), central memory (Tcm), effector memory (Tem) and tissue-resident memory (Trm)] that all have specific functionalities. To stimulate antigen-specific CTLs, biomaterials should present peptide $\mathrm{MHC}(\mathrm{pMHC})$ class I, agonistic antibodies that trigger co-stimulatory receptors for signal 2 and cytokines as signal 3 as depicted. (B) To trigger differentiation of CD4 ${ }^{+} \mathrm{T}$ cells into T helper 1 (Th1) and Th17 cells, biomaterials need to present pMHC class II together with co-stimulatory signals and different combinations of cytokines. As an alternative to agonistic antibodies to trigger co-stimulatory signaling pathways, natural ligands of co-stimulatory receptors can be used.

results of a mouse melanoma study showed that the $\mathrm{T}$ helper 17 (Th17) subset producing IL-17 was involved in B16 tumor rejection (37). Other studies have also indicated a positive role for Th17 cells in the development of long-term anti-tumor immunity and their help in CTL activation and recruitment to the tumor $(38,39)$. Besides providing support to CTLs, CD4 ${ }^{+}$ $\mathrm{T}$ cells can also contribute to the anti-tumor immune response independent of $\mathrm{CD}^{+} \mathrm{T}$ cells $(30,40,41)$ by acquiring cytotoxic activity and executing a direct anti-tumor effect $(36,40)$. Finally, $\mathrm{CD}^{+}{ }^{+} \mathrm{T}$ regulatory cells (Tregs) mainly encompass the immune inhibitory subset, which is important in physiological settings to prevent autoimmunity (35). Due to their immune inhibitory profile, Tregs can prevent tumor clearance by inhibiting CTL functions (42).

The generation of the various $\mathrm{CD} 4^{+} \mathrm{T}$ cell subsets in vitro is mainly determined by the cytokine profile present during $\mathrm{T}$ cell receptor-mediated activation (34). The presence of interleukin12 (IL-12) and IFN- $\gamma$ will skew $\mathrm{CD}^{+} \mathrm{T}$ cells toward a Th1 profile, while the presence of TGF- $\beta$, IL- 6 and IL- 21 will drive the differentiation toward a Th17 profile (34) (Figure 1B).
Besides inducing Th1 differentiation, IL-12 also enhances the proliferation of activated $\mathrm{T}$ cells and induces cell-mediated immunity (43). In addition, IL-1 is able to directly act on CD4 ${ }^{+} \mathrm{T}$ cells, especially IL-17 producing cells, increasing antigen-specific T cell expansion and enhancing survival (Figure 1B) (44).

Taken together, these studies emphasize the importance of inducing potent CTL and stimulatory $\mathrm{CD} 4^{+} \mathrm{T}$ helper cell subsets (in particular Th1 and Th17 cells) to induce potent anti-tumor responses, but they also highlight the need for differentiation of the effector subsets into memory cells to help prevent relapse. Insight into the molecular cues that can optimize the design of biomaterial strategies to gain control over the repertoire of T cells that is induced is therefore pivotal.

\section{MOLECULAR CUES TO ACTIVATE AND EXPAND T CELLS}

To provide $\mathrm{T}$ cells with the signals that are required for activation and differentiation, inspiration could be sought in the 
mechanism of action of natural antigen-presenting cells (APCs) for $\mathrm{T}$ cell priming, thereby creating aAPCs. Three fundamental signals for $\mathrm{T}$ cell activation are (i) triggering TCR signaling; (ii) adequate co-stimulation, e.g., through the CD28 signaling axis; and (iii) the availability of cytokines to direct $\mathrm{T}$ cell differentiation $(45,46)$. TCR engagement can be mimicked by agonistic $\alpha$ CD3 antibodies for polyclonal T cell expansion or recombinant $\mathrm{MHC}$ peptide complexes (pMHC) for antigen-specific T cell expansion. Artificial co-stimulation can be provided using agonistic $\alpha \mathrm{CD} 28$ antibodies or recombinant natural ligands CD80 (B7.1) and CD86 (B7.2). Recombinant cytokines that provide signal 3 are widely available and are typically presented in soluble form.

Various biomaterial designs have been synthesized to mimic DCs which vary in their shape, the signals they present and the method of administration (19, 47) (Figure 2A). Traditionally, soluble polymers or polymeric beads presenting agonistic $\alpha \mathrm{CD} 3 / \alpha \mathrm{CD} 28$ antibodies to $\mathrm{T}$ cells are used to induce vigorous polyclonal expansion. Besides CD28, costimulatory signals belonging to the tumor necrosis factor receptor superfamily (TNFRSF), such as OX-40, 4-1BB, CD27, and LIGHT, are also potentially interesting to steer $\mathrm{T}$ cell activation (56, 57). Though OX-40, 4-1BB and CD27 can perform co-stimulation for both $\mathrm{CD}^{+}$and $\mathrm{CD}^{+} \mathrm{T}$ cells, OX-40 was shown to predominantly act as a co-stimulatory molecule for $\mathrm{CD}^{+} \mathrm{T}$ cells (58-61). Engagement of 4$1 \mathrm{BB}$ and $\mathrm{CD} 27$ were more prone to induce potent $\mathrm{CD} 8^{+}$ activation. An aAPC design presenting $\alpha \mathrm{CD} 3$ antibodies with $\alpha 4-1 B B$ antibodies as the co-stimulatory cue was reported to preferentially expand memory cells and induce enhanced cytolytic activity compared to aAPCs presenting $\alpha \mathrm{CD} 3$ and aCD28 (62). CD27 co-stimulation enhances activation and survival of $\mathrm{CD}^{+} \mathrm{T}$ cells $(60,61)$, prevents activation-induced cell death (60) and supports the presence of tumor-specific $\mathrm{CD}^{+}$ $\mathrm{T}$ cells residing within established melanoma (63). Expression of LIGHT in the tumor microenvironment of patients increases $\mathrm{T}$ cell expansion, activation and infiltration and correlates with improved clinical outcome $(64,65)$. Furthermore, LIGHT signaling enhanced $\mathrm{T}$ cell proliferation, IFN- $\gamma$ production, tumor infiltration and regression of established tumors in a P815 mastocytoma tumor model and a CT26 colon cancer model $(57,64)$. These studies imply that careful tuning of costimulatory cues presented by biomaterials can steer $\mathrm{T}$ cell priming and functionality.

The third signal consisting of cytokines is especially important for naïve $\mathrm{CD}^{+} \mathrm{T}$ cells to differentiate, develop their effector functions, and form potent memory populations (66). Absence of this third signal can result in deletion or anergy of the activated cells $(67,68)$. In a normal immunological setting, $\mathrm{CD}^{+}{ }^{+} \mathrm{T}$ helper cells promote IL-12 or type I IFN production by DCs in a CD40-dependent manner to ensure potent CTL development $(67,68)$. Apart from supplying $\mathrm{T}$ cells with recombinant cytokines presented by biomaterials, the adaptor molecule Stimulator of IFN Gene (STING) could be used to induce type I IFN production $(69,70)$. Besides IL-12 and type I IFN, there are various other cytokines involved in $\mathrm{T}$ cell activation and differentiation such as IL2, IL-7, IL-15 and IL-21 (Figure 1A) (66). IL-7, IL-15 and
IL-21 are important for $\mathrm{CD}^{+} \mathrm{T}$ cell memory formation and maintenance (71), while IL-2 promotes the expansion of both $\mathrm{CD}^{+}$and $\mathrm{CD}^{+} \mathrm{T}$ cells, thus augmenting the effector T-cell response (72). Moreover, cytokines steer CD4 ${ }^{+}$ $\mathrm{T}$ cell development into the different subsets (34), which emphasizes the necessity to include these signals into a biomaterial design.

\section{MOLECULAR CUES TO GENERATE T CELLS OF HIGH QUALITY}

Not only the quantity of the generated $\mathrm{T}$ cells is important, as the quality needs also to be considered. When $\mathrm{T}$ cells reach a more differentiated state, the cell effector functions increase while the memory functions and proliferation capacity decrease (26). Experimental studies in mice and patients have shown a superior role for less differentiated cells (Tscm and $\mathrm{Tcm}$ ) in adoptive cell transfer, as was demonstrated by enhanced engraftment, expansion, persistence and antitumor responses of these minimally differentiated $\mathrm{T}$ cells in vivo $(28,73-77)$.

The low numbers of circulating Tscm (28) cells have resulted in the development of in vitro culture practices where the differentiation of naïve $\mathrm{T}$ cells is controlled by supplementing culture media with IL-7 plus IL-15 or IL-21 and/or small molecules to activate the $\mathrm{Wnt} / \beta$-catenin pathway $(71,78)$. The cells generated with these culture protocols showed increased engraftment, expansion and higher tumor reactivity $(71,78)$. In addition, longer expansion time of $\mathrm{T}$ cells ex vivo can also drive $\mathrm{T}$ cell differentiation and negatively affect cytolytic activity, proliferation, tumor control and $\mathrm{T}$ cell persistence in vivo (79).

$\mathrm{T}$ cell differentiation may also be influenced by $\mathrm{T}$ cell metabolism. TILs cultured with a small inhibitory drug for protein kinase B (AKT) (80), naïve $\mathrm{T}$ cells cultured with an inhibitor for mammalian target of rapamycin (mTOR) (81) and $\mathrm{CD}^{+} \mathrm{T}$ cells exposed to 2-hydroxyglutarate (82) induces $\mathrm{T}$ cells with transcriptional and metabolic properties characteristic of memory $\mathrm{T}$ cells that show increased persistence and anti-tumor response in vivo after adoptive transfer. These studies indicate the importance of $\mathrm{T}$ cell quality and how this may affect persistence, proliferation, survival and effector functions in vivo, and demonstrate possibilities for improving ex vivo $\mathrm{T}$ cell cultures that could also be highly relevant in designing biomaterial-based systems for $\mathrm{T}$ cell expansion.

The multifunctionality of the effector $\mathrm{T}$ cells also influences the quality of the generated $\mathrm{T}$ cells (72). T cells are considered to be multifunctional when having two or more functions including, but not limited to, the production of cytokines, chemokines and/or degranulation (72). Multifunctional CD4 ${ }^{+}$ and $\mathrm{CD}^{+} \mathrm{T}$ cells are able to secrete more IFN $\gamma$, and $\mathrm{T}$ cells producing both IFN $\gamma$ and TNF can mediate more efficient killing compared to single cytokine-producing cells (72). Even though these are illustrations from the field of infectious diseases, multifunctional effector $\mathrm{T}$ cell responses could also benefit antitumor immunity. 


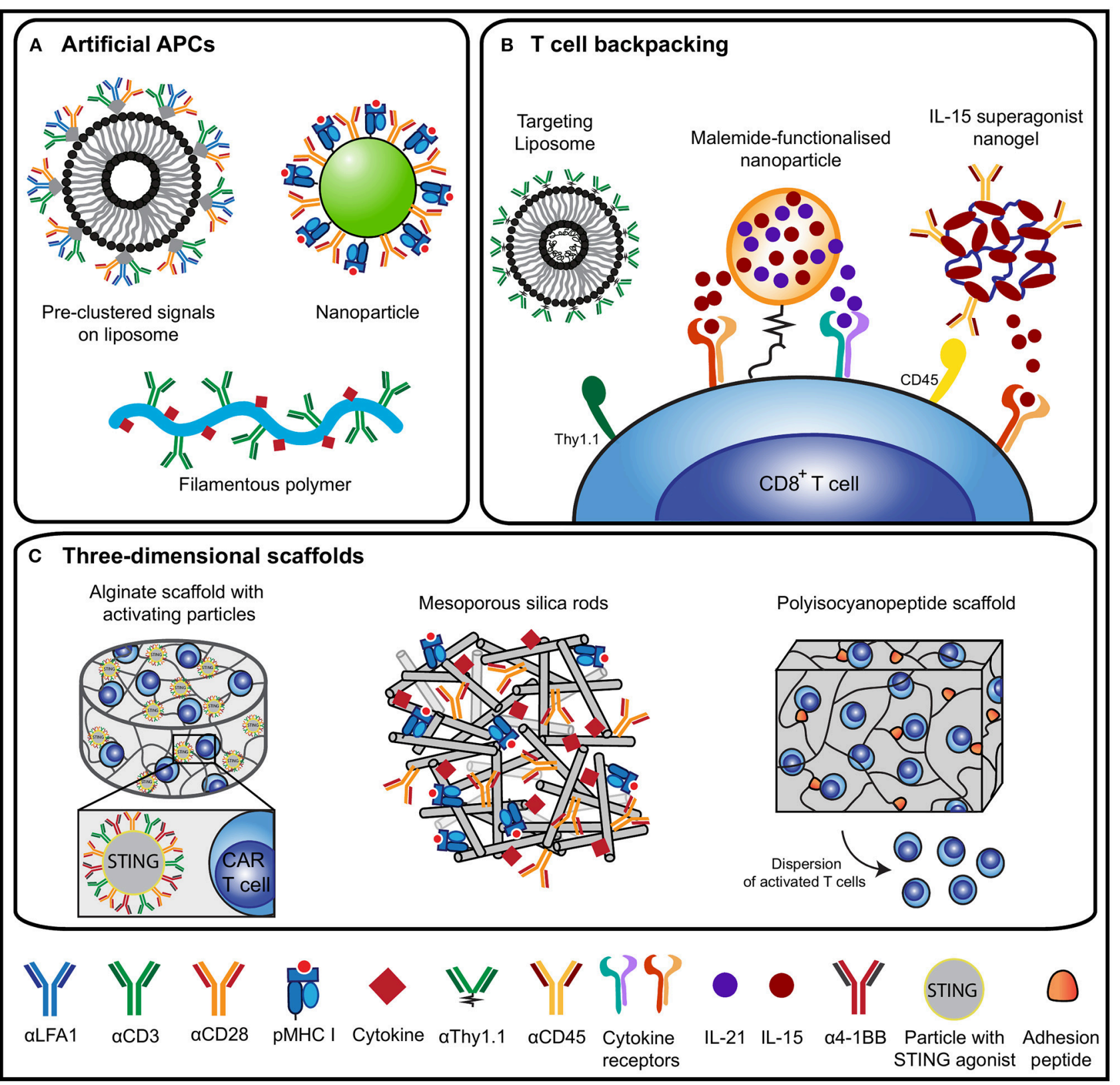

FIGURE 2 | Overview of biomaterial design strategies for T cell activation and expansion. (A) An overview of design strategies of artificial antigen-presenting cells (aAPCs) based on liposomes (48), nanoparticles (19) or filamentous polymers (49). aAPC designs present various molecular cues to induce T cell activation, including $\mathrm{pMHC}$ or $\alpha \mathrm{CD} 3$ antibodies as signal 1, $\alpha \mathrm{CD} 28$ antibodies to mimic signal 2 and cytokines as signal 3. (B) Different T cell backpacking strategies for the ex vivo or in vivo targeting of cytokine-loaded particles to T cells using antibody as targets [liposome (50) and nanogel (51)] or through chemical [binding (52) (nanoparticle)]. These strategies ensure targeted delivery of cytokines to support persistence of adoptively transferred cells in vivo. (C) 3D scaffold-based strategies to expand T cells and to support adoptively transferred (CAR) T cells. Designs include alginate scaffolds with stimulatory microparticles for CAR T cell expansion (53), mesoporous silica rods for T cell activation (54) and a synthetic polyisocyanopeptide-based scaffold that disperses T cells (55).

\section{DESIGNING BIOMATERIALS FOR OPTIMAL TUMOR-SPECIFIC T CELL PRIMING}

Biomaterials can be used to present the three imperative signals to $\mathrm{T}$ cells to support activation, expansion and differentiation in a spatiotemporally well-defined and sustained manner (83). The defined structural nature of biomaterials enables chemical modification to introduce desired functionalities through standard conjugation or bio-orthogonal chemistries such as "click chemistry" (84, 85). The characteristics of the biomaterial, such as biodegradability, biocompatibility, half-life and the implementation of biological targeting moieties, but also physical properties such as shape, surface topology and mechanical properties, can shape the interaction 
with $\mathrm{T}$ cells and thus alter the immune response that is provoked (86).

The context in which molecular cues are provided can also influence $\mathrm{T}$ cell responses. Immobilizing signal 1 on a surface was reported to promote robust $\mathrm{T}$ cell activation (87), because physical forces play an important role in TCR signal transduction (88). The relevance of force upon the TCR was interrogated in more detail by making use of materials with different stiffness $(89,90)$. MHC class I molecules presented on a softer poly(dimethylsioxane) surface led to enhanced $\mathrm{T}$ cell proliferation, improved IL-2 production and increased Th1 differentiation compared to TCR engagement using rigid polystyrene beads $(89,90)$. In addition to the effect of material stiffness, polymeric aAPC presenting $\mathrm{T}$ cell-stimulating cues in a multivalent context demonstrated the importance of multivalency for long-lasting $\mathrm{T}$ cell activation $(91,92)$. Furthermore, superior $\mathrm{CD} 8^{+} \mathrm{T}$ cell activation was observed for biomaterials displaying signals 1 and 2 in a pre-clustered manner $(19,47,93,94)$, for instance on liposomes (48). Signal density also affects $\mathrm{T}$ cell responses, as $\mathrm{CD} 4^{+} \mathrm{T}$ cells were reported to remain unresponsive when signal 1 is presented in a density that is too low (95-97). In addition to signal density, the quantity of signals 1 and 2 can also influence the effector Th1 $\mathrm{CD}^{+}$and effector $\mathrm{CD} 8^{+} \mathrm{T}$ cell responses (72). Limited amounts of signal 1 or 2 were shown to induce Th1 cells and $\mathrm{CD}^{+}{ }^{+} \mathrm{T}$ cells that only secrete IFN $\gamma$, while in the presence of increased concentrations of signal 1 or 2 cells both IFN $\gamma$ and IL-2 were secreted $(98,99)$.

Most biomaterial designs implement cytokines (signal 3) either in release vesicles or via adsorption $(47,54,100)$, creating a local high concentration of soluble cytokines. Robust $\mathrm{T}$ cell activation can also be obtained with immobilized cytokines and might preferentially deliver these to $\mathrm{T}$ cells through copresentation of $\mathrm{T}$ cell-specific antibodies (49), providing a new range of possibilities for the addition of cytokines in biomaterialbased immune therapies.

When using biomaterials, care must be taken to prevent the induction of exhausted $\mathrm{T}$ cells due to persisting $\mathrm{T}$ cell stimulation, leading to diminished cytokine production, reduced proliferative capacity, decreased killing abilities, and high expression of coinhibitory molecules, such as PD-1 and CLTA-4 (101). Therefore, one should not only focus on trying to induce a strong activation signal, but special care should be taken to achieve appropriate stimulation levels to ensure desired $\mathrm{T}$ cell activation and prevent $\mathrm{T}$ cell exhaustion. To prevent or counteract the exhausted state of $\mathrm{T}$ cells, the biomaterial might need to be equipped with PD- 1 and CTLA-4 blocking antibodies. Several biomaterial designs have been tested to improve the delivery and sustained release of these antibodies, displaying improved anti-tumor efficacy $(14,102)$. An alternative strategy to prevent $\mathrm{T}$ cell exhaustion could be to provide co-stimulation with an $\alpha \mathrm{CD} 2$ antibody (103).

\section{BIOMATERIALS FOR ADOPTIVE T CELL TRANSFER}

Apart from applying biomaterials to prime and expand $\mathrm{T}$ cells with stimulatory cues, biomaterials are also excellent tools to support the adoptive transfer of $\mathrm{T}$ cells for cancer immunotherapeutic purposes (Figures 2B,C). Adoptive $\mathrm{T}$ cell therapy (ACT) has shown promising results in inducing durable anti-tumor immune responses $(1,7,8)$. However, efficacy generally depends on the co-administration of lymphodepleting chemotherapy and/or high doses of IL-2 to support the persistence of these cells in vivo $(1,104,105)$. Biomaterials have been designed to reduce toxicities seen with the systemic administration of these adjuvants and to enhance the response of adoptively transferred cells $(51,52)$ (Figure 2B). In an elegant design of liposome-like synthetic nanoparticles that encapsulate IL-15 superagonist and IL-21, reduced thiol groups on the $\mathrm{T}$ cell surface were used to covalently bind nanoparticles onto the cells before ACT (52). These "backpacks" resulted in considerably more proliferation and persistence of the transferred cells in vivo and led to complete tumor clearance in mice bearing metastasized B16F10 melanoma. Further development led to stimuli-responsive particles that release IL15 superagonist upon increased redox activity at the $\mathrm{T}$ cell surface upon TCR signaling (51). To enable repeated in vivo stimulation of adoptively transferred $\mathrm{T}$ cells, particles were designed that target $\mathrm{T}$ cells through an $\alpha$ Thyl.1 antibody or IL-2 (50). To circumvent the need to culture cells ex vivo, $\alpha \mathrm{CD} 3$ antibody fragments can be used to target biodegradable poly $(\beta$-amino ester)-based nanoparticles to $\mathrm{T}$ cells in vivo. These nanoparticles contained a DNA plasmid encoding a leukemia-specific CAR gene combined with 4-1BB and CD3ל cytoplasmic signaling domains. This strategy resulted in the in vivo generation of CAR-T cells that perform comparable to CAR-T cells generated using the conventional ex vivo culture method (106).

Most biomaterials for $\mathrm{T}$ cell activation are designed to function in soluble form or in suspension as two-dimensional systems. Limited work has been performed using threedimensional (3D) scaffold-based designs for $\mathrm{T}$ cell activation, whereas within the field of DC activation there are multiple examples of 3D scaffolds to create local DC-recruiting and activating niches. 3D scaffolds have proven advantageous as they present DCs with activating cues in a sustained manner at a localized site (107-109). We believe that designing such scaffolds and thereby creating synthetic immune niches for localized in vivo $\mathrm{T}$ cell activation could contribute significantly to the current $\mathrm{T}$ cell mediated anticancer therapies. A synthetic immune niche as a site of $\mathrm{T}$ cell priming and dispersion could replace or augment the function of tumor-draining lymph nodes, which were shown to be key regulators in the anti-tumor immune response (110).

One area in which $3 \mathrm{D}$ scaffolds have been explored for $\mathrm{T}$ cell activation is in the field of ACT (Figure 2C). An alginate implant equipped with $\mathrm{T}$ cell-stimulating signals $(\alpha \mathrm{CD} 3, \alpha \mathrm{CD} 28$, $\alpha 4-1 \mathrm{BB}$, and IL-15 superagonist) and migration-promoting peptides induced a substantial increase in the proliferation of adoptively transferred $\mathrm{T}$ cells at the tumor resection site in a 4T1 mouse breast tumor model (100). Moreover, these cells did not acquire an exhausted phenotype, but migrated toward the tumor-draining lymph nodes where they differentiated into 
central memory $\mathrm{T}$ cells. In another alginate-based scaffold approach, a combination of adoptive transfer of CAR-T cells and the incorporation of a STING agonist was used to trigger anti-tumor host immunity (53). A chitosan thermogel has also been tested for ACT and resulted in a supportive environment where antigen-specific $\mathrm{T}$ cells could proliferate and subsequently migrate toward target cells, which were effectively killed in vitro (111). Mesoporous silica microrods with supported lipid bilayers were used to provide $\mathrm{T}$ cells with either polyclonal cues $(\alpha C D 3)$ or antigen-specific cues (pMHC) in combination with $\alpha \mathrm{CD} 28$ for co-stimulation and adsorbed IL-2 to provide paracrine delivery of cytokines (54). Alternatively, a fully-synthetic hydrogel composed of triethylene glycol-substituted polyisocyanopeptides functionalized with integrin-binding motifs supported the ex vivo expansion and survival of $\mathrm{T}$ cells (55). The ex vivo-stimulated $\mathrm{T}$ cells could successfully egress from the hydrogel over time when administered in vivo, identifying these hydrogels as effective cellular delivery vehicles. Together, these studies demonstrate proof of the concept that $3 \mathrm{D}$ scaffolds can be used as a multifunctional platform to enhance polyclonal and antigen-specific $\mathrm{T}$ cell expansion and cell persistence in vivo.

The use of biomaterials for the adoptive transfer of $\mathrm{T}$ cells might make ACT more efficient, as ex vivo culture time could be reduced and be potentially superfluous. This would make ACT more feasible and at the same time benefit $\mathrm{T}$ cell functionality (105). Moreover, implementing molecular cues like IL-7, IL-15, or IL-21 in 3D biomaterialbased scaffolds could provide an in vivo immune niche for the generation and support of adoptively transferred Tscm, which in turn could improve in vivo $\mathrm{T}$ cell persistence, proliferation and anti-tumor response $(71,78)$, underlining the promise of biomaterial-based $3 \mathrm{D}$ scaffolds for $\mathrm{T}$ cell activation in vivo. Careful investigation of the behavior of $\mathrm{T}$ cells in response to different combinations of molecular cues is required to create the most desirable $\mathrm{T}$ cell-activating synthetic immune niche.

\section{CONCLUDING REMARKS}

Biomaterials are highly promising tools to present molecular cues to $\mathrm{T}$ cells to evoke robust immune responses both in vitro and in vivo. In this perspective, we presented an overview of molecular cues that could be used to selectively expand $\mathrm{T}$ cell subsets that are beneficial for strong anti-tumor immune responses. Biomaterials can be exploited to control the presentation of specific combinations of these molecular cues to $\mathrm{T}$ cells and can thus be used to regulate the stimulation level and the induction of specific $\mathrm{T}$ cell phenotypes. Careful consideration of how to combine the insights on important $\mathrm{T}$ cell-activating molecular cues with material-intrinsic factors is highly important for the design of biomaterials for the expansion and activation of tumor-specific $\mathrm{T}$ cells. In this respect, biomaterials could be used as tools to delineate the molecular cues and scaffold design parameters that dictate $\mathrm{T}$ cells' responses. When designing biomaterials for controlled activation of the immune system, it is important to take into account the intrinsic immunogenicity of materials and the potential change in immunomodulatory properties after biodegradation (112, 113). In our opinion, one of the major factors that needs to be considered is implementing potent $\mathrm{CD}^{+}{ }^{+} \mathrm{T}$ helper cues alongside $\mathrm{CD}^{+}{ }^{+} \mathrm{T}$ cell signals on biomaterials. In particular, tuning the $\mathrm{T}$ helper response toward a more Th1 and/or Th17 response might have considerable effects on clinical outcomes. Moreover, an improved understanding of the cues essential for memory cell formation is needed in order to develop biomaterial designs that can elicit long-term memory and thus better protect against tumor recurrence. It will be imperative to pursue a balanced and controlled system in terms of number and the release kinetics of molecular cues and the biodegradability of the biomaterial of choice (114).

As is evident from the studies discussed above, biomaterialbased cancer vaccines constitute a very promising field, but a number of challenges remain, especially those related to clinical translation. The ultimate goal is clinical application of biomaterial-based systems to induce long-term and systemic anti-cancer immunity in cancer patients. To ensure smooth transition to clinical translation, it is important to recognize key design parameters from the beginning of the design process, such as biomaterial composition, reproducible and largescale production under good manufacturing practice (GMP), in vivo behavior, degradation, toxicities and safety. This can contribute to decreasing the time and cost of the regulatory pathway. Cell-free biomaterials for local administration, like $3 \mathrm{D}$ scaffolds, typically need less extensive testing to get approval, due to limited risks of systemic toxicities (115). However, local toxicity and inflammation may still arise and need to be carefully tested. The soluble biomaterial strategies, such as the particle-based aAPCs, might be considered as biologicals which would indicate a longer and more expensive regulatory pathway. Moreover, modifying already existing and approved therapeutic designs, including materials such as poly(lactic-co-glycolic acid) (PLGA) and hyaluronic acid, will allow for a clearer regulatory pathway (115). The field of regenerative medicine has already contributed a range of clinically-approved biomaterial products from which biomaterial-based cancer immunotherapies may benefit (115, 116). Besides meeting the safety criteria, the biomaterial-based cancer immunotherapies will need to demonstrate efficacy in appropriate preclinical animal tumor models when compared to current therapies (116).

The backpacking of adoptively transferred cells using particle-based biomaterials is considered to have great clinical promise $(51,52)$. In the beginning of this year, a phase 1 clinical trial with these biomaterial-based $\mathrm{T}$ cell backpacks started in patients with solid tumors and lymphomas (117). This example, together with the developments and future directions described in this perspective, illustrates that innovative designs of biomaterials for the direct activation of $\mathrm{T}$ cells will bring clinical implementation of biomaterialbased expansion and differentiation of tumor-reactive $\mathrm{T}$ cells closer. 


\section{AUTHOR CONTRIBUTIONS}

MS, RH, CF, MV, and JW contributed to researching the data for the article, discussing the content and to reviewing and editing the manuscript before submission. MS, MV, and JW were responsible for writing the article.

\section{REFERENCES}

1. Martin-Liberal J, Ochoa de Olza M, Hierro C, Gros A, Rodon J, Tabernero J. The expanding role of immunotherapy. Cancer Treat Rev. (2017) 54:7486. doi: 10.1016/j.ctrv.2017.01.008

2. Banchereau J, Steinman RM. Dendritic cells and the control of immunity. Nature. (1998) 392:245-52. doi: 10.1038/32588

3. Palucka K, Banchereau J. Cancer immunotherapy via dendritic cells. Nat Rev Cancer. (2012) 12:265-77. doi: 10.1038/nrc3258

4. Guo C, Manjili MH, Subjeck JR, Sarkar D, Fisher PB, Wang X-Y. Therapeutic cancer vaccines: past, present, and future. Adv Cancer Res. (2013) 119:42175. doi: 10.1016/B978-0-12-407190-2.00007-1

5. Bol KF, Aarntzen EH, Hout FE, Schreibelt G, Creemers JH, Lesterhuis WJ, et al. Favorable overall survival in stage III melanoma patients after adjuvant dendritic cell vaccination. Oncoimmunology. (2016) 5:e1057673. doi: 10.1080/2162402X.2015.1057673

6. Restifo NP, Dudley ME, Rosenberg SA. Adoptive immunotherapy for cancer: harnessing the T cell response. Nat Rev Immunol. (2012) 12:26981. doi: 10.1038/nri3191

7. Rosenberg SA, Restifo NP. Adoptive cell transfer as personalized immunotherapy for human cancer. Science. (2015) 348:628. doi: $10.1126 /$ science.aaa4967

8. Jackson HJ, Rafiq S, Brentjens RJ. Driving CAR T-cells forward. Nat Rev Clin Oncol. (2016) 13:370-83. doi: 10.1038/nrclinonc.2016.36

9. Fridman WH, Galon J, Pages F, Tartour E, Sautes-Fridman C, Kroemer G. Prognostic and predictive impact of intra- and peritumoral immune infiltrates. Cancer Res. (2011) 71:56015. doi: 10.1158/0008-5472.CAN-11-1316

10. Knocke S, Fleischmann-Mundt B, Saborowski M, Manns MP, Kühnel F, Wirth TC, et al. Tailored tumor immunogenicity reveals regulation of CD4 and CD8 T cell responses against cancer. Cell Rep. (2016) 17:223446. doi: 10.1016/j.celrep.2016.10.086

11. Kreiter S, Vormehr M, van de Roemer N, Diken M, Löwer M, Diekmann J, et al. Mutant MHC class II epitopes drive therapeutic immune responses to cancer. Nature. (2015) 520:692-6. doi: 10.1038/nature14426

12. Lu Z-R, Qiao P. Drug delivery in cancer therapy, Quo Vadis? Mol Pharm. (2018) 15:3603-16. doi: 10.1021/acs.molpharmaceut.8b 00037

13. Gammon JM, Dold NM, Jewell CM. Improving the clinical impact of biomaterials in cancer immunotherapy. Oncotarget. (2016) 7:1542143. doi: 10.18632 /oncotarget.7304

14. Xie Y-Q, Wei L, Tang L. Immunoengineering with biomaterials for enhanced cancer immunotherapy. Wiley Interdiscip Rev Nanomed Nanobiotechnol. (2018) 10:e1506. doi: 10.1002/wnan.1506

15. Graciotti M, Berti C, Klok H-A, Kandalaft L. The era of bioengineering: how will this affect the next generation of cancer immunotherapy? J Transl Med. (2017) 15:142. doi: 10.1186/s12967-017-1244-2

16. Lynn GM, Laga R, Darrah PA, Ishizuka AS, Balaci AJ, Dulcey AE, et al. In vivo characterization of the physicochemical properties of polymer-linked TLR agonists that enhance vaccine immunogenicity. Nat Biotechnol. (2015) 33:1201-10. doi: 10.1038/nbt.3371

17. Duan F, Feng X, Yang X, Sun W, Jin Y, Liu H, et al. A simple and powerful co-delivery system based on $\mathrm{pH}$-responsive metal-organic frameworks for enhanced cancer immunotherapy. Biomaterials. (2017) 122:23-33. doi: 10.1016/j.biomaterials.2017.01.017

18. Liu Q, Chen X, Jia J, Zhang W, Yang $T$, Wang L, et al. pHResponsive poly(D,L-lactic-co-glycolic acid) nanoparticles with rapid

\section{FUNDING}

This work was supported by the Oncode Institute and the Institute of Chemical Immunology (grant 024.002.009). CF received the NWO Spinoza award. MV is recipient of ERC Starting grant CHEMCHECK (679921) and a Gravity Program Institute for Chemical Immunology tenure track grant by NWO.

antigen release behavior promote immune response. ACS Nano. (2015) 9:4925-38. doi: 10.1021/nn5066793

19. Hickey JW, Vicente FP, Howard GP, Mao H-Q, Schneck JP. Biologically inspired design of nanoparticle artificial antigenpresenting cells for immunomodulation. Nano Lett. (2017) 17:7045-54. doi: 10.1021/acs.nanolett.7b03734

20. Eggermont LJ, Paulis LE, Tel J, Figdor CG. Towards efficient cancer immunotherapy: advances in developing artificial antigen-presenting cells. Trends Biotechnol. (2014) 32:456-65. doi: 10.1016/j.tibtech.2014.06.007

21. Halle S, Halle O, Förster R. Mechanisms and dynamics of $\mathrm{T}$ cell-mediated cytotoxicity in vivo. Trends Immunol. (2017) 38:432-43. doi: 10.1016/j.it.2017.04.002

22. Gerlach C, Moseman EA, Loughhead SM, Alvarez D, Zwijnenburg AJ, Waanders $\mathrm{L}$, et al. The chemokine receptor CX3CR1 defines three antigen-experienced CD8 T cell subsets with distinct roles in immune surveillance and homeostasis. Immunity. (2016) 45:1270-84. doi: 10.1016/j.immuni.2016.10.018

23. Böttcher JP, Beyer M, Meissner F, Abdullah Z, Sander J, Höchst B, et al. Functional classification of memory CD ${ }^{+} \mathrm{T}$ cells by CX3CR1 expression. Nat Commun. (2015) 6:8306. doi: 10.1038/ncomms9306

24. He R, Hou S, Liu C, Zhang A, Bai Q, Han M, et al. Follicular CXCR5expressing $\mathrm{CD}^{+} \mathrm{T}$ cells curtail chronic viral infection. Nature. (2016) 537:412-28. doi: 10.1038/nature19317

25. Chang JT, Wherry EJ, Goldrath AW. Molecular regulation of effector and memory $\mathrm{T}$ cell differentiation. Nat Immunol. (2014) 15:110415. doi: 10.1038/ni.3031

26. Mahnke YD, Brodie TM, Sallusto F, Roederer M, Lugli E. The who's who of T-cell differentiation: human memory T-cell subsets. Eur J Immunol. (2013) 43:2797-809. doi: 10.1002/eji.201343751

27. Gattinoni L, Speiser DE, Lichterfeld M, Bonini C. T memory stem cells in health and disease. Nat Med. (2017) 23:18-27. doi: 10.1038/nm.4241

28. Gattinoni L, Lugli E, Ji Y, Pos Z, Paulos CM, Quigley MF, et al. A human memory T cell subset with stem cell-like properties. Nat Med. (2011) 17:1290-7. doi: 10.1038/nm.2446

29. Palucka K, Banchereau J. Dendritic-cell-based therapeutic cancer vaccines. Immunity. (2013) 39:38-48. doi: 10.1016/j.immuni.2013.07.004

30. Muranski P, Restifo NP. Adoptive immunotherapy of cancer using CD4+ T cells. Curr Opin Immunol. (2009) 21:200-8. doi: 10.1016/j.coi.2009.02.004

31. Wong SBJ, Bos R, Sherman LA. Tumor-specific CD4+ T cells render the tumor environment permissive for infiltration by low-avidity CD ${ }^{+} \mathrm{T}$ Cells. J Immunol. (2008) 180:3122-31. doi: 10.4049/jimmunol.180.5.3122

32. Gao FG, Khammanivong V, Liu WJ, Leggatt GR, Frazer IH, Fernando GJP. Antigen-specific $\mathrm{CD} 4^{+}$T-cell help is required to activate a memory CD8 ${ }^{+}$ T cell to a fully functional tumor killer cell. Cancer Res. (2002) 62:6438-41. Available online at: http://cancerres.aacrjournals.org/content/62/22/6438. long

33. Nakayamada S, Takahashi H, Kanno Y, O'Shea JJ. Helper $\mathrm{T}$ cell diversity and plasticity. Curr Opin Immunol. (2012) 24:297-302. doi: 10.1016/j.coi.2012.01.014

34. Zhu J, Yamane H, Paul WE. Differentiation of effector CD4 T cell populations. Annu Rev Immunol. (2010) 28:44589. doi: 10.1146/annurev-immunol-030409-101212

35. Fridman WH, Pagès F, Sautès-Fridman C, Galon J. The immune contexture in human tumours: impact on clinical outcome. Nat Rev Cancer. (2012) 12:298-306. doi: 10.1038/nrc3245

36. Nishimura T, Nakui M, Sato $M$, Iwakabe K, Kitamura H, Sekimoto $M$, et al. The critical role of Th1-dominant immunity in tumor immunology. 
Cancer Chemother Pharmacol. (2000) 46:S52-61. doi: 10.1007/PL000 14051

37. Muranski P, Boni A, Antony PA, Cassard L, Irvine KR, Kaiser A, et al. Tumorspecific Th17-polarized cells eradicate large established melanoma. Blood. (2008) 112:362-73. doi: 10.1182/blood-2007-11-120998

38. Martin-Orozco N, Muranski P, Chung Y, Yang XO, Yamazaki T, Lu S, et al. $\mathrm{T}$ helper 17 cells promote cytotoxic $\mathrm{T}$ cell activation in tumor immunity. Immunity. (2009) 31:787-98. doi: 10.1016/j.immuni.2009.09.014

39. Muranski P, Borman ZA, Kerkar SP, Klebanoff CA, Ji Y, Sanchez-Perez L, et al. Th17 cells are long lived and retain a stem cell-like molecular signature. Immunity. (2011) 35:972-85. doi: 10.1016/j.immuni.2011.09.019

40. Quezada SA, Simpson TR, Peggs KS, Merghoub T, Vider J, Fan X, et al. Tumor-reactive $\mathrm{CD} 4^{+} \mathrm{T}$ cells develop cytotoxic activity and eradicate large established melanoma after transfer into lymphopenic hosts. J Exp Med. (2010) 207:637-50. doi: 10.1084/jem.20091918

41. Xie Y, Akpinarli A, Maris C, Hipkiss EL, Lane M, Kwon EK, et al. Naive tumor-specific $\mathrm{CD}^{+} \mathrm{T}$ cells differentiated in vivo eradicate established melanoma. J Exp Med. (2010) 207:651-67. doi: 10.1084/jem.200 91921

42. Tanchot C, Terme M, Pere H, Tran T, Benhamouda N, Strioga M, et al. Tumor-infiltrating regulatory $\mathrm{T}$ cells: phenotype, role, mechanism of expansion in situ and clinical significance. Cancer Microenviron. (2013) 6:147-57. doi: 10.1007/s12307-012-0122-y

43. Del Vecchio M, Bajetta E, Canova S, Lotze MT, Wesa A, Parmiani G, et al. Interleukin-12: biological properties and clinical application. Clin Cancer Res. (2007) 13:4677-85. doi: 10.1158/1078-0432.CCR-07 $-0776$

44. Ben-Sasson SZ, Hu-Li J, Quiel J, Cauchetaux S, Ratner M, Shapira I, et al. IL-1 acts directly on CD4 T cells to enhance their antigen-driven expansion and differentiation. Proc Natl Acad Sci USA. (2009) 106:711924. doi: $10.1073 /$ pnas. 0902745106

45. Frankenberger B, Schendel DJ. Third generation dendritic cell vaccines for tumor immunotherapy. Eur J Cell Biol. (2012) 91:53-8. doi: 10.1016/j.ejcb.2011.01.012

46. Bakdash G, Sittig SP, van Dijk T, Figdor CG, de Vries IJM. The nature of activatory and tolerogenic dendritic cell-derived signal II. Front Immunol. (2013) 4:53. doi: 10.3389/fimmu.2013.00053

47. Fadel TR, Sharp FA, Vudattu N, Ragheb R, Garyu J, Kim D, et al. A carbon nanotube-polymer composite for T-cell therapy. Nat Nanotechnol. (2014) 9:639-47. doi: 10.1038/nnano.2014.154

48. Zappasodi R, Di Nicola M, Carlo-Stella C, Mortarini R, Molla A, Vegetti $\mathrm{C}$, et al. The effect of artificial antigen-presenting cells with preclustered anti-CD28/-CD3/-LFA-1 monoclonal antibodies on the induction of ex vivo expansion of functional human antitumor T cells. Haematologica. (2008) 93:1523-34. doi: 10.3324/haematol.12521

49. Eggermont LJ, Hammink R, Blank KG, Rowan AE, Tel J, Figdor CG. Cytokine-functionalized synthetic dendritic cells for T cell targeted immunotherapies. Adv Ther. (2018) 1:1800021. doi: 10.1002/adtp.2018 00021

50. Zheng Y, Stephan MT, Gai SA, Abraham W, Shearer A, Irvine DJ. In vivo targeting of adoptively transferred T-cells with antibodyand cytokine-conjugated liposomes. J Control Release. (2013) 172:42635. doi: 10.1016/j.jconrel.2013.05.037

51. Tang L, Zheng Y, Melo MB, Mabardi L, Castaño AP, Xie Y-Q, et al. Enhancing $\mathrm{T}$ cell therapy through TCR-signaling-responsive nanoparticle drug delivery. Nat Biotechnol. (2018) 36:707-16. doi: 10.1038/nbt.4181

52. Stephan MT, Moon JJ, Um SH, Bershteyn A, Irvine DJ. Therapeutic cell engineering with surface-conjugated synthetic nanoparticles. Nat Med. (2010) 16:1035-41. doi: 10.1038/nm.2198

53. Smith TT, Moffett HF, Stephan SB, Opel CF, Dumigan AG, Jiang X, et al. Biopolymers codelivering engineered $\mathrm{T}$ cells and STING agonists can eliminate heterogeneous tumors. J Clin Invest. (2017) 127:217691. doi: 10.1172/JCI87624

54. Cheung AS, Zhang DKY, Koshy ST, Mooney DJ. Scaffolds that mimic antigen-presenting cells enable ex vivo expansion of primary T cells. Nat Biotechnol. (2018) 36:160-9. doi: 10.1038/nbt.4047

55. Weiden J, Voerman D, Dölen Y, Das RK, van Duffelen A, Hammink R, et al. Injectable biomimetic hydrogels as tools for efficient $\mathrm{T}$ cell expansion and delivery. Front Immunol. (2018) 9:2798. doi: 10.3389/fimmu.2018. 02798

56. Buchan SL, Rogel A, Al-Shamkhani A. The immunobiology of CD27 and OX40 and their potential as targets for cancer immunotherapy. Blood. (2017) 131:39-48. blood-2017-07-741025. doi: 10.1182/blood-2017-07-741025

57. Tamada K, Shimozaki K, Chapoval AI, Zhu G, Sica G, Flies D, et al. Modulation of T-cell-mediated immunity in tumor and graft-versus-host disease models through the LIGHT co-stimulatory pathway. Nat Med. (2000) 6:283-9. doi: $10.1038 / 73136$

58. Taraban VY, Rowley TF, O'Brien L, Chan HT, Haswell LE, Green $\mathrm{MH}$, et al. Expression and costimulatory effects of the TNF receptor superfamily members CD134 (OX40) and $\mathrm{CD} 137$ (4-1BB), and their role in the generation of antitumor immune responses. Eur J Immunol. (2002) 32:361727. doi: 10.1002/1521-4141(200212)32:12<3617::AID-IMMU3617>3.0.CO;2$\mathrm{M}$

59. Kurche JS, Burchill MA, Sanchez PJ, Haluszczak C, Kedl RM. Comparison of OX40 ligand and CD70 in the promotion of CD4+ T cell responses. $J$ Immunol. (2010) 185:2106-15. doi: 10.4049/jimmunol.1000172

60. Hendriks J, Xiao Y, Borst J. CD27 promotes survival of activated T cells and complements CD28 in generation and establishment of the effector T cell pool. J Exp Med. (2003) 198:1369-80. doi: 10.1084/jem.200 30916

61. Soares H, Waechter H, Glaichenhaus N, Mougneau E, Yagita H, Mizenina O, et al. A subset of dendritic cells induces $\mathrm{CD} 4^{+} \mathrm{T}$ cells to produce IFN- $\gamma$ by an IL-12-independent but CD70-dependent mechanism in vivo. J Exp Med. (2007) 204:1095-106. doi: 10.1084/jem.20070176

62. Zhang H, Snyder KM, Suhoski MM, Maus MV, Kapoor V, June CH, et al. $4-1 \mathrm{BB}$ is superior to CD28 costimulation for generating CD8+ cytotoxic lymphocytes for adoptive immunotherapy. J Immunol. (2007) 179:49108. doi: 10.4049/jimmunol.179.7.4910

63. Roberts DJ, Franklin NA, Kingeter LM, Yagita H, Tutt AL, Glennie $\mathrm{M}$, et al. Control of established melanoma by $\mathrm{CD} 27$ stimulation is associated with enhanced effector function and persistence, and reduced PD-1 expression of tumor infiltrating CD8+ T cells. J Immunother. (2010) 33:769-79. doi: 10.1097/CJI.0b013e3181ee238f

64. Qiao G, Qin J, Kunda N, Calata JF, Mahmud DL, Gann P, et al. LIGHT elevation enhances immune eradication of colon cancer metastases. Cancer Res. (2017) 77:1880-91. doi: 10.1158/0008-5472.CAN-16-1655

65. Maker AV, Ito $\mathrm{H}, \mathrm{Mo} \mathrm{Q}$, Weisenberg E, Qin L-X, Turcotte S, et al. Genetic evidence that intratumoral T-cell proliferation and activation are associated with recurrence and survival in patients with resected colorectal liver metastases. Cancer Immunol Res. (2015) 3:380-8. doi: 10.1158/2326-6066.CIR-14-0212

66. Valbon SF, Condotta SA, Richer MJ. Regulation of effector and memory $\mathrm{CD} 8^{+} \mathrm{T}$ cell function by inflammatory cytokines. Cytokine. (2016) 82:1623. doi: $10.1016 /$ j.cyto.2015.11.013

67. Mescher MF, Curtsinger JM, Agarwal P, Casey KA, Gerner M, Hammerbeck CD, et al. Signals required for programming effector and memory development by $\mathrm{CD}^{+} \mathrm{T}$ cells. Immunol Rev. (2006) 211:81-92. doi: 10.1111/j.0105-2896.2006.00382.x

68. Curtsinger JM, Mescher MF. Inflammatory cytokines as a third signal for $\mathrm{T}$ cell activation. Curr Opin Immunol. (2010) 22:333-40. doi: 10.1016/j.coi.2010.02.013

69. Temizoz B, Kuroda E, Ohata K, Jounai N, Ozasa K, Kobiyama K, et al. TLR9 and STING agonists synergistically induce innate and adaptive type-II IFN. Eur J Immunol. (2015) 45:1159-69. doi: 10.1002/eji.201445132

70. Moore E, Clavijo PE, Davis R, Cash H, Van Waes C, Kim Y, et al. Established $\mathrm{T}$ cell-inflamed tumors rejected after adaptive resistance was reversed by combination STING activation and PD-1 pathway blockade. Cancer Immunol Res. (2016) 4:1061-71. doi: 10.1158/2326-6066.CIR-16-0104

71. Sabatino M, Hu J, Sommariva M, Gautam S, Fellowes V, Hocker JD, et al. Generation of clinical-grade CD19-specific CAR-modified CD8+ memory stem cells for the treatment of human B-cell malignancies. Blood. (2016) 128:519-28. doi: 10.1182/blood-2015-11-683847

72. Seder RA, Darrah PA, Roederer M. T-cell quality in memory and protection: implications for vaccine design. Nat Rev Immunol. (2008) 8:24758. doi: $10.1038 /$ nri2274 
73. Zhou J, Shen X, Huang J, Hodes RJ, Rosenberg SA, Robbins PF. Telomere length of transferred lymphocytes correlates with in vivo persistence and tumor regression in melanoma patients receiving cell transfer therapy. $J$ Immunol. (2005) 175:7046-52. doi: 10.4049/jimmunol.175.10.7046

74. Klebanoff CA, Gattinoni L, Palmer DC, Muranski P, Ji Y, Hinrichs CS, et al. Determinants of successful $\mathrm{CD}^{+} \mathrm{T}$-cell adoptive immunotherapy for large established tumors in mice. Clin Cancer Res. (2011) 17:534352. doi: 10.1158/1078-0432.CCR-11-0503

75. Rosenberg SA, Yang JC, Sherry RM, Kammula US, Hughes MS, Phan GQ, et al. Durable complete responses in heavily pretreated patients with metastatic melanoma using T-cell transfer immunotherapy. Clin Cancer Res. (2011) 17:4550-7. doi: 10.1158/1078-0432.CCR-11-0116

76. Gattinoni L, Zhong X-S, Palmer DC, Ji Y, Hinrichs CS, Yu Z, et al. Wnt signaling arrests effector $\mathrm{T}$ cell differentiation and generates CD8+ memory stem cells. Nat Med. (2009) 15:808-13. doi: 10.1038/nm.1982

77. Sommermeyer D, Hudecek M, Kosasih PL, Gogishvili T, Maloney DG, Turtle CJ, et al. Chimeric antigen receptor-modified $\mathrm{T}$ cells derived from defined $\mathrm{CD}^{+}$and $\mathrm{CD}^{+}{ }^{+}$subsets confer superior antitumor reactivity in vivo. Leukemia. (2016) 30:492-500. doi: 10.1038/leu.2015.247

78. Cieri N, Camisa B, Cocchiarella F, Forcato M, Oliveira G, Provasi E, et al. IL-7 and IL-15 instruct the generation of human memory stem T cells from naive precursors. Blood. (2013) 121:573-84. doi: 10.1182/blood-2012-05-431718

79. Ghassemi S, Nunez-Cruz S, O'Connor RS, Fraietta JA, Patel PR, Scholler $\mathrm{J}$, et al. Reducing ex vivo culture improves the antileukemic activity of Chimeric Antigen Receptor (CAR) T cells. Cancer Immunol Res. (2018) 6:1100-9. doi: 10.1158/2326-6066.CIR-17-0405

80. Crompton JG, Sukumar M, Roychoudhuri R, Clever D, Gros A, Eil $\mathrm{RL}$, et al. Akt inhibition enhances expansion of potent tumor-specific lymphocytes with memory cell characteristics. Cancer Res. (2015) 75:296305. doi: 10.1158/0008-5472.CAN-14-2277

81. Scholz G, Jandus C, Zhang L, Grandclément C, Lopez-Mejia IC, Soneson C, et al. Modulation of mTOR signalling triggers the formation of stem cell-like memory $\mathrm{T}$ cells. EBioMedicine. (2016) 4:50-61. doi: 10.1016/j.ebiom.2016.01.019

82. Tyrakis PA, Palazon A, Macias D, Lee KL, Phan AT, Veliça P, et al. S-2-hydroxyglutarate regulates $\mathrm{CD}^{+}$T-lymphocyte fate. Nature. (2016) 540:236-41. doi: 10.1038/nature20165

83. Anderson DG. Materials science: smart biomaterials. Science. (2004) 305:1923-4. doi: 10.1126/science.1099987

84. Anseth KS, Klok H-A. Click chemistry in biomaterials, nanomedicine, and drug delivery. Biomacromolecules. (2016) 17:1-3. doi: 10.1021/acs.biomac.5b01660

85. Hvilsted S. Facile design of biomaterials by 'click' chemistry. Polym Int. (2012) 61:485-94. doi: 10.1002/pi.4135

86. Mitragotri S, Lahann J. Physical approaches to biomaterial design. Nat Mater. (2009) 8:15-23. doi: 10.1038/nmat2344

87. Geppert TD, Lipsky PE. Accessory cell independent proliferation of human T4 cells stimulated by immobilized monoclonal antibodies to CD3. J Immunol. (1987) 138:1660-6.

88. Li YC, Chen BM, Wu PC, Cheng TL, Kao LS, Tao MH, et al. Cutting edge: mechanical forces acting on $\mathrm{T}$ cells immobilized via the TCR complex can trigger TCR signaling. J Immunol. (2010) 184:595963. doi: 10.4049/jimmunol.0900775

89. O'Connor RS, Hao X, Shen K, Bashour K, Akimova T, Hancock $\mathrm{WW}$, et al. Substrate rigidity regulates human $\mathrm{T}$ cell activation and proliferation. J Immunol. (2012) 189:1330-9. doi: 10.4049/jimmunol.11 02757

90. Lambert LH, Goebrecht GKE, De Leo SE, O'Connor RS, Nunez-Cruz S, Li T-D, et al. Improving T cell expansion with a soft touch. Nano Lett. (2017) 17:821-6. doi: 10.1021/acs.nanolett.6b04071

91. Hammink R, Mandal S, Eggermont LJ, Nooteboom M, Willems PHGM, Tel J, et al. Controlling T-cell activation with synthetic dendritic cells using the multivalency effect. ACS Omega. (2017) 2:937-45. doi: 10.1021/acsomega.6b00436

92. Mandal S, Eksteen-Akeroyd ZH, Jacobs MJ, Hammink R, Koepf M, Lambeck AJA, et al. Therapeutic nanoworms: towards novel synthetic dendritic cells for immunotherapy. Chem Sci. (2013) 4:4168. doi: 10.1039/c3sc5 $1399 \mathrm{~h}$
93. Alarcón B, Mestre D, Martínez-Martín N. The immunological synapse: a cause or consequence of T-cell receptor triggering? Immunology. (2011) 133:420-5. doi: 10.1111/j.1365-2567.2011. 03458.x

94. Mandal S, Hammink R, Tel J, Eksteen-Akeroyd ZH, Rowan AE, Blank $\mathrm{K}$, et al. Polymer-based synthetic dendritic cells for tailoring robust and multifunctional T cell responses. ACS Chem Biol. (2015) 10:48592. doi: $10.1021 / \mathrm{cb} 500455 \mathrm{~g}$

95. Delcassian D, Depoil D, Rudnicka D, Liu M, Davis DM, Dustin ML, et al. Nanoscale ligand spacing influences receptor triggering in $\mathrm{T}$ cells and NK cells. Nano Lett. (2013) 13:5608-14. doi: 10.1021/nl40 3252x

96. Matic J, Deeg J, Scheffold A, Goldstein I, Spatz JP. Fine tuning and efficient $\mathrm{T}$ cell activation with stimulatory aCD3 nanoarrays. Nano Lett. (2013) 13:5090-7. doi: 10.1021/nl4022623

97. Deeg J, Axmann M, Matic J, Liapis A, Depoil D, Afrose J, et al. T cell activation is determined by the number of presented antigens. Nano Lett. (2013) 13:5619-26. doi: 10.1021/nl403266t

98. Itoh Y, Germain RN. Single cell analysis reveals regulated hierarchical T cell antigen receptor signaling thresholds and intraclonal heterogeneity for individual cytokine responses of CD4 + T cells. J Exp Med. (1997) 186:75766. doi: 10.1084/jem.186.5.757

99. La Gruta NL, Turner SJ, Doherty PC. Hierarchies in cytokine expression profiles for acute and resolving influenza virus-specific CD8+ $\mathrm{T}$ cell responses: correlation of cytokine profile and TCR avidity. J Immunol. (2004) 172:5553-60. doi: 10.4049/jimmunol.172. 9.5553

100. Stephan SB, Taber AM, Jileaeva I, Pegues EP, Sentman CL, Stephan MT. Biopolymer implants enhance the efficacy of adoptive Tcell therapy. Nat Biotechnol. (2015) 33:97-101. doi: 10.1038/nbt. 3104

101. Wherry EJ. T cell exhaustion. Nat Immunol. (2011) 12:4929. doi: $10.1038 /$ ni.2035

102. Francis DM, Thomas SN. Progress and opportunities for enhancing the delivery and efficacy of checkpoint inhibitors for cancer immunotherapy. Adv Drug Deliv Rev. (2017) 114:33-42. doi: 10.1016/j.addr.2017. 04.011

103. McKinney EF, Lee JC, Jayne DRW, Lyons PA, Smith KGC. T-cell exhaustion, co-stimulation and clinical outcome in autoimmunity and infection. Nature. (2015) 523:612-6. doi: 10.1038/nature14468

104. Rosenberg SA. IL-2: the first effective immunotherapy for human cancer. J Immunol. (2014) 192:5451-8. doi: 10.4049/jimmunol.14 90019

105. Hinrichs CS, Rosenberg SA. Exploiting the curative potential of adoptive T-cell therapy for cancer. Immunol Rev. (2014) 257:56-71. doi: 10.1111/imr.12132

106. Smith TT, Stephan SB, Moffett HF, McKnight LE, Ji W, Reiman $\mathrm{D}$, et al. In situ programming of leukaemia-specific $\mathrm{T}$ cells using synthetic DNA nanocarriers. Nat Nanotechnol. (2017) 12:813-20. doi: 10.1038/nnano.2017.57

107. Kim J, Li WA, Choi Y, Lewin SA, Verbeke CS, Dranoff G, et al. Injectable, spontaneously assembling, inorganic scaffolds modulate immune cells in vivo and increase vaccine efficacy. Nat Biotechnol. (2015) 33:6472. doi: 10.1038/nbt.3071

108. Bencherif SA, Warren Sands R, Ali OA, Li WA, Lewin SA, Braschler TM, et al. Injectable cryogel-based whole-cell cancer vaccines. Nat Commun. (2015) 6:7556. doi: 10.1038/ncomms8556

109. Weiden J, Tel J, Figdor CG. Synthetic immune niches for cancer immunotherapy. Nat Rev Immunol. (2017) 18:2129. doi: $10.1038 /$ nri.2017.89

110. Fransen MF, Schoonderwoerd M, Knopf P, Camps MG, Hawinkels LJ, Kneilling $M$, et al. Tumor-draining lymph nodes are pivotal in PD-1/PD-L1 checkpoint therapy. JCI Insight. (2018) 3:124507. doi: 10.1172/jci.insight.124507

111. Monette A, Ceccaldi C, Assaad E, Lerouge S, Lapointe R. Chitosan thermogels for local expansion and delivery of tumor-specific T lymphocytes towards enhanced cancer immunotherapies. Biomaterials. (2016) 75:23749. doi: 10.1016/j.biomaterials.2015.10.021 
112. Andorko JI, Hess KL, Pineault KG, Jewell CM. Intrinsic immunogenicity of rapidly-degradable polymers evolves during degradation. Acta Biomater. (2016) 32:24-34. doi: 10.1016/j.actbio.2015.12.026

113. Andorko JI, Pineault KG, Jewell CM. Impact of molecular weight on the intrinsic immunogenic activity of poly(beta amino esters). J Biomed Mater Res A. (2017) 105:1219-29. doi: 10.1002/jbm.a.35970

114. Wang $\mathrm{H}$, Mooney DJ. Biomaterial-assisted targeted modulation of immune cells in cancer treatment. Nat Mater. (2018) 17:761-72. doi: 10.1038/s41563-018-0147-9

115. Pashuck ET, Stevens MM. Designing regenerative biomaterial therapies for the clinic. Sci Transl Med. (2012) 4:160sr4. doi: 10.1126/scitranslmed.3002717

116. Hollister SJ. Scaffold design and manufacturing: from concept to clinic. $A d v$ Mater. (2009) 21:3330-42. doi: 10.1002/adma.200802977
117. US National Library of Medicine. ClinicalTrials.gov. (2019) Available online at: https://www.clinicaltrials.gov/ct2/show/NCT03815682

Conflict of Interest Statement: The authors declare that the research was conducted in the absence of any commercial or financial relationships that could be construed as a potential conflict of interest.

Copyright (c) 2019 Schluck, Hammink, Figdor, Verdoes and Weiden. This is an openaccess article distributed under the terms of the Creative Commons Attribution License (CC BY). The use, distribution or reproduction in other forums is permitted, provided the original author(s) and the copyright owner(s) are credited and that the original publication in this journal is cited, in accordance with accepted academic practice. No use, distribution or reproduction is permitted which does not comply with these terms. 